\title{
MOBILE EMERGENCY SERVICES: THE ACTIONS OF THE NURSING TEAM IN SITUATIONS OF VIOLENCE
}

\author{
SERVIÇO DE ATENDIMENTO MÓVEL DE URGÊNCIA: ATUAÇÃO DA EQUIPE \\ DE ENFERMAGEM EM OCORRENCIAS VIOLENTAS
}

\section{Fernanda Carolina CAMARGO ${ }^{1}$; Luan Augusto Alves GARCIA ${ }^{2}$; Ana Carolina Rodrigues de LUCENA ${ }^{3}$; Helena Hemiko IWAMOTO ${ }^{4}$; Regiane Máximo de SOUZA ${ }^{5}$, Sergio Antonio ZULLO ${ }^{6}$; Álvaro da Silva SANTOS ${ }^{7}$}

\begin{abstract}
1. PhD in Health Care from Federal University of Triângulo Mineiro; 2. Master in Health Care from Federal University of Triângulo Mineiro; 3. Nurse graduated from the Federal University of Triângulo Mineiro; 4. PhD in Nursing; 5. PhD in Production Engineering. Professor at the Department of Production Engineering and Graduate Program in Production Engineering at the State University of São Paulo Júlio de Mesquita Filho; 6. Master of Statistics; 7. PhD in Social Sciences. Post-doctorate Studies in Social Services. Associate professor of the Post-graduation Programs in Health Care and Psychology and of the Nursing Education and Community Health Department at University of Triângulo Mineiro.
\end{abstract}

\begin{abstract}
This study aimed to evaluate the profile of attention of the mobile emergency services in cases of violence and the actions of the nursing team. Observational, exploratory and analytical study were undertaken from secondary records. A Correspondence Analysis was conducted to identify the associations between the actions of the nursing team and the profile of the necessity of care due to violent causes. The results showed that from 1800 cases, most took place during the weekend (49.2\%), involving men (70.0\%) and traffic accidents $(76.5 \%)$. The correspondence analysis highlighted two dimensions $(76.7 \%$ of explanatory contribution), resulting in three similar groups considering the nursing professional taking part in the attention, how the situation ended, period in which it occurred, and profile of the victim. The performed analysis was strategic for the systematization of data which gave support to the situational understanding of the composition of the service and for the planning of the actions of the nursing team.
\end{abstract}

KEYWORDS: Emergency Medical Services. Emergency Nursing. Nursing Team. External Causes. Violence.

\section{INTRODUCTION}

The pre-hospital attention settings have specificities in which there are challenges to the health of the patient, to the quality of care and to the adequate attention in emergency situations. When one considers the Mobile Emergency Services (SAMU, in the Brazilian acronym) as the Brazilian mobile emergency care service, the realities are similar to the challenges mentioned above (BRICE et al., 2012; SOUZA et al., 2014).

Specially, since these services are brought to effect in dynamic and unpredictable daily occurrences, these health demands are considered to be complex systems (BRICE et al., 2012; SOUZA et al., 2014). The recognition of the way in which pre-hospital attention takes place in the day-to-day work is increasingly necessary, so that attention to urgencies is made effective by the qualified actions of the professionals who work in the front lines in these situations.

Considering how recently the Network of Attention to Urgencies and Emergencies of the Unified Health System was created, being instituted in Brazil in 2011, assessments of its composition in the different places where it was instituted become more and more important (KONDER; O'DWYER, 2015).

On the other hand, SAMU, in Brazil, despite being one of the main components responsible for bringing into effect the Network of Attention to Urgencies and Emergencies - Unified Health System, had been implanted nationally since 2004 . It is a $24 / 7$ service, made up of health professionals - physicians, nurses, nursing technicians - rescuers, who offer attention anywhere - houses, workplaces, public spaces, among others. The emergency care takes place after one calls, free of charge, 192. In this context, this service has the important role of safeguarding lives within our society (KONDER; O'DWYER, 2015).

Although literature is full of examples of the importance of mobile emergency services to save lives and limit damages caused by sudden health problems, violence and disasters (WILLIAMS, 2012), national and international scientific publications that analyze the composition of these services are scarce, as are those which discuss the 
spatial distribution of these events and the identification of overload periods for these services (BRICE et al., 2012; WILLIAMS, 2012; SOUZA et al., 2014).

Another necessary aspect of the mobile emergency services that needs to be evaluated are the actions of the Nursing professional. In general, the importance of the nursing team is highlighted due to its front role in the settings of emergency mobile care, since this type of work leads to emotional and physical distress, while simultaneously requiring specialized technical qualifications (ALVES et al., 2013; WILLIAMS, 2012; SOUZA et al., 2014).

The actions of the nurse in the SAMU integrates activities related to the direct care and response to the calls; administrative activities such as managing data banks, supplying materials and equipment and elaborating schedules; educational activities such as continued education of the team and training sessions for the population as a whole (ALVES et al., 2013). From this perspective, understanding the profile of the care which is needed in these calls during each period would help the actions of the nurse in these settings.

It should be mentioned that, with regards to the demands for assistance, urban centers have a higher number of demands due to violent causes. This reality affects our society, especially, due to the changes brought about by the fast and disordered urbanization, coupled with social inequality (BRICE et al., 2012; WILLIAMS, 2012; SOUZA et al., 2014).

Violent acts are called external causes, when evaluated by the International Disease Classification (GONSAGA et al., 2015). Confronting them is a complex task, which demands intersectoral mobilization, including the appropriate aid to be offered to the victims in the sites of violent occurrences. It is also important to highlight the relevance of this type of health hazards in a global scale. The aims for the millennium of the United Nations Organization, intended to change the world up to 2030 , includes, as its 16 th objective, a significant reduction of all types of violence and related mortality rates (UNITED NATIONS, 2013).

Overall, since the health conditions of the population are directly associated to health services, a discussion on the composition of pre-hospital services of mobile care in the attention to violent occurrences becomes paramount. Two questions emerge from this context: What is the profile of the occurrences related to violent causes to which the Mobile emergency services respond? What are the actions taken by the nursing team as they respond to these occurrences? As a result, this study aimed to evaluate the profile of the attention offered by the mobile emergency services regarding occurrences involving violent causes and the actions taken by the nursing team in such occurrences.

\section{MATERIAL AND METHODS}

This is an observational, exploratory and analytical study made with information from secondary records of a mobile emergency service of a city in the region of Triângulo Mineiro. This municipality is a health hub of the macro-region Triângulo Sul and has 302,623 residents, $97.8 \%$ of which live in an urban area (BRAZILIAN INSTITUTE OF GEOGRAPHY AND STATISTICS, 2012). SAMU was implanted there in July 2007. It currently has one Advanced Support Unit, three Basic Support Units and one common ambulance, named "Águia". It includes 99 workers, $85.1 \%$ of which are nursing professionals.

Data collection took place in the service itself from Augusto to September 2016. Records (service records) related to the occurrences to which the service responded from August/2015 to July/2016 were analyzed. These records, belonging to the service, are filled in to help typifying the care and the composition of the teams of the ambulances in their responses to calls.

In order to extract the data from the records, guidelines were elaborated by the authors, including the following variables of interest: sex, cause of the occurrence (traffic accident, aggression, suicide/self-inflicted violence), time of day the ambulances were sent to respond to the occurrence, day of the week, month and year in which the occurrence took place, nursing team that responded to the occurrence (whether it was a complete - nurse and nursing technician - or incomplete - just nursing technician - team), and what was the outcome of the occurrence (if the victim was sent to the hospital, to an Emergency Care Unit, or care was offered immediately in the place of the occurrence). The variables regarding the period of the day in which the ambulance was dispatched considered four periods of six hours each: 1st period $-00 \mathrm{~h}: 00$ to 05h:59; 2nd period - 06h:00 to $11 \mathrm{~h}: 59$; 3rd period 12h:00 to $17 \mathrm{~h}: 59$; 4th period $-18 \mathrm{~h}: 00$ to $23 \mathrm{~h}: 59$. The files that were incomplete or did not have the variables of interest to this research were excluded from the study.

A descriptive analysis of data was conducted according to absolute and relative frequencies. As a result, the correspondence analysis was carried out to explore the connections between 
the composition of the nursing team and the profile of the necessity of care due to violent causes (INFANTOSI; COSTA; ALMEIDA, 2014).

A correspondence analysis is a technique that uses associations between categoric variables, without the need of the pre-definition of a causal structure neither an aprioristic probability distribution. The instruments made up a databank in Excel ${ }^{\circledR}$, which was created by independent double entry. The tabulation of the databank generated a matrix in which the lines corresponded to the occurrences originating from violent causes and the columns to the variables of interest. The categories corresponding to each variable were regrouped, and later transformed and codified, so that a correspondence analysis could be conducted (INFANTOSI; COSTA; ALMEIDA, 2014).

The occurrences made up similarity groups when they presented, globally, the same modalities. The proximity in the factorial plan (perceptual map) graphically translated the observed fact. The distance used to evaluate the similarity between the lines and columns was chi-square $\left(\mathrm{X}^{2}\right)$.

The following transformed variables were used to investigate whether there were associations between the variables: a) the composition of the nursing team (in this study, understood as the group of variables which corresponded to the team that acted in the occurrence and to its outcome) and b) other variables of the study - all of which were treated as active variables. The importance of each variable in the construction of the axis was measured through relative contribution, which was found through the multiplication of the absolute value of the contribution by $100(\operatorname{Cos} 2 \%)$ and with the eigenvalues. The analysis of the absolute contribution of the categories together with the observation of the position of the points in the graph in relation to the axis, helped the interpretation of the factors and contributed for the conceptual characterization of the groups that presented with similarities. It is important to note that the relationships between geometric proximity and the position in the factorial plan help identify associations between variables. The statistical analysis was conducted with the use of the software StatSoft. Inc. (2007) - Statistica.

The study respected all formal requirements of national and international regulations for researches involving human beings. It was approved by the Research Ethics Committee of the Federal University of Triangulo Mineiro, Brazil, protocol $\mathrm{n}^{\circ}$. 2714, in accordance with Resolution CNS 196/96 and derivatives.

\section{RESULTS}

1,073 records were analyzed and 173 were excluded due to incomplete information or empty fields, to a total of 1,800 occurrences involving violent causes in the studied period. Regarding the distribution of the occurrences in the months, days and times of day, the periods with a higher concentration of such occurrences was found to be from March to May 2016 (31.5\% of occurrences) and from Friday to Sunday ( $49.2 \%$ of occurrences). Regarding the time of day, the cases took place mostly from 6:00 a.m. to 11:59 a.m. and from 6:00 p.m. to $11: 59$ p.m $(34.4 \%$ and $37.3 \%$ o cases, respectively). The lowest incidence was in the period from 12:00 a.m. to 05:59 a.m (4.4\%).

In regards to the profile of the people attended, most were males $(70.0 \%)$, occurrences involved, respectively, auto accidents (76.5\%), aggression $(19.2 \%)$ and self-inflicted violence (4.3\%). Only $17.5 \%$ of calls were responded by the complete nursing team (which includes nurses and nursing technicians). Most victims were referred to hospitals $(53.8 \%)$, followed by those referred to Emergency Care Units (29.4\%), being that the minority of cases were dealt with in their original locations (16.8\%). Regarding the correspondence analysis, the dimensions 1 and 2 stood out, with respective eigenvalues of 0.081 and 0.039 . Coupled, they presented an explanatory contribution of $76.7 \%$ of total variability, being that Dimension 1 contributed with $51.6 \%$ and Dimension 2 with $25.1 \%$. The detailing of the many active variables and their specific contributions were expressed in Table 1.

Table 1. Description of the similarity groups according to the codes and captions for the active variables, and relative contribution $(\mathrm{Cos} 2 \%)$ in the factorial axes.

\begin{tabular}{ccccc}
\hline \multirow{2}{*}{ Groups } & \multirow{2}{*}{ Codes } & \multicolumn{2}{c}{ Contributions (Cos2 \%) } & Caption (Codes) \\
\cline { 3 - 4 } & & Y-axis & X-axis & Complete team, Emergency Care \\
\cline { 3 - 5 } & $\mathrm{CU}$ & 87.2 & 1.9 & Complete team, local aid \\
& $\mathrm{CN}$ & 78.3 & 0.3 & Men and women (respectively) victimized by auto
\end{tabular}




\begin{tabular}{|c|c|c|c|c|}
\hline & FT1 & 17.5 & 602 & accidents (12:00 a.m. - 05:59 p.m) \\
\hline & MV3 & 22.7 & 2.5 & Male victims of aggression (12:00 p.m. - 5:59 p.m; \\
\hline & MV4 & 22.7 & 0.1 & 6:00 p.m - 11:59 p.m, respectively) \\
\hline & MA2 & 54.4 & 15.3 & Men, attempted suicide \\
\hline & MA3 & 82.9 & 1.6 & (6:00 a.m. - 11:59 a.m; 12:00 p.m - 5:59 p.m; 6:00 \\
\hline & MA4 & 95.6 & 0.9 & p.m - 11:59 p.m, respectively) \\
\hline & FA1 & 34.0 & 0.2 & $\begin{array}{l}\text { Women, attempted suicide } \\
\text { (12:00 a.m. - 05:59 a.m.) }\end{array}$ \\
\hline & $\mathrm{CH}$ & 0.0 & 92.1 & Complete team, hospital \\
\hline & MV1 & 0.4 & 83.6 & Male victims of aggression \\
\hline$\stackrel{n}{=}$ & MV2 & 7,4 & 82,8 & (12:00 a.m - 5:59 a.m, respectively) \\
\hline 苞 & FV2 & 1,2 & 28,7 & Female victims of aggression \\
\hline$\ddot{\partial}$ & FV3 & 0.1 & 60.6 & (6:00 a.m. - 11:59 a.m; 12:00 p.m - 5:59 p.m; 6:00 \\
\hline ?ำ & FV4 & 1.4 & 85.9 & p.m - 11:59 p.m, respectively) \\
\hline בֶ & MA1 & 52.8 & 31.3 & $\begin{array}{l}\text { Men, attempted suicide } \\
\text { (12:00 a.m. - 05:59 a.m.) }\end{array}$ \\
\hline ్ㅗㄱ & FA2 & 9.7 & 82.3 & Women, attempted suicide \\
\hline & FA3 & 10.3 & 65.2 & (6:00 a.m. - $11: 59$ a.m; 12:00 p.m - 5:59 p.m; 6:00 \\
\hline & FA4 & 4.7 & 66.4 & p.m - 11:59 p.m, respectively) \\
\hline & IU & 23.0 & 44.1 & Incomplete team, Emergency Care \\
\hline & $\mathrm{IH}$ & 46.7 & 1.8 & Incomplete team, hospital \\
\hline$\stackrel{\mathscr{n}}{=}$ & IN & 24.0 & 2.6 & Incomplete team, local aid \\
\hline$\frac{\pi}{3}$ & MT2 & 79.5 & 6.5 & Male victims of aggression (06:00 a.m. - 11:59 \\
\hline$\stackrel{\pi}{ٍ}$ & MT3 & 84.1 & 2.2 & a.m.; 12:00 p.m. - 5:59 p.m; 6:00 p.m - 11:59 p.m, \\
\hline 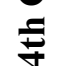 & MT4 & 1.4 & 77.7 & respectively) \\
\hline$\stackrel{0}{\Xi}$ & FT2 & 85.9 & 11.3 & Female victims of aggression (06:00 a.m. - 11:59 \\
\hline$\overbrace{}^{\pi}$ & FT3 & 92.4 & 2.4 & a.m.; 12:00 p.m. - 5:59 p.m; 6:00 p.m - 11:59 p.m, \\
\hline & FT4 & 2.7 & 1.1 & respectively) \\
\hline & FV1 & 12.0 & 1.0 & $\begin{array}{l}\text { Female victims of aggression } \\
\text { (12:00 a.m. - 05:59 a.m.) }\end{array}$ \\
\hline
\end{tabular}

In sequence, the active variables were presented by their graphical distribution, demonstrating their geometric proximity and the position of each, according to the factorial axes. Regarding the factorial plan (perceptual map) three similarity groups were identified. Note that the codes of the variables in the perceptual map correspond to the same captions as in Image I. The group from the 1st quadrant corresponded to the actions of the complete nursing team in cases whose attention did not take place in the hospital. The team responded to occurrences: at night (from 12:00 a.m. to 05:59 a.m.) - women who were victims of aggression and auto accidents in both genders; 12:00 p.m. to 11:59 p.m. - men who attempted suicide (self-inflicted violence); from 6:00 a.m. to 23:59 p.m. - men who were victims of aggression. In the 2nd and 3rd quadrants, the group corresponded to: the complete nursing team and a referral to the hospital, which was responsible for occurrences during the night (From 12:00 a.m. to 05:59 a.m.) - men who were victims of aggression; from the night until lunch time (from 12:00 a.m. to 11:59 p.m.) - attempted suicide by women; from 6:00 a.m. to 11:59 a.m. - attempted suicide by women and women victims of aggression. Between the 3rd and 4th quadrants, the group corresponded to: the nursing team consisting of only nursing technicians, with different outcomes (assistance offered on site, referrals to Emergency Units and to 
the Hospital). The occurrences were made up of: during the night (from 12:00 a.m. to 05:59 a.m.) attempted suicide by women; and from 6:00 a.m. to
11:59 p.m. - auto accidents involving either sex (Figure 1).

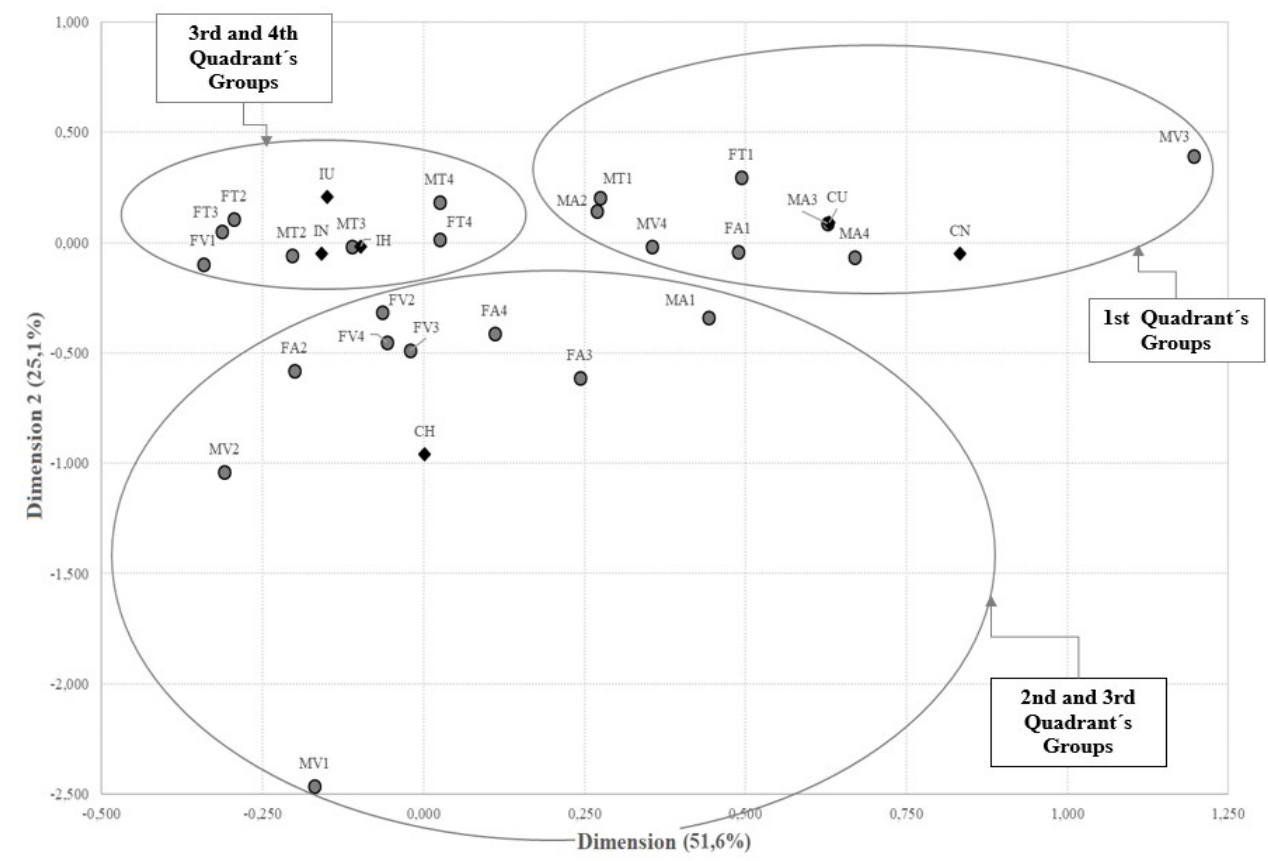

Figure 1. Perceptual map of the similar groups according to the actions of the nursing team regarding the attention to occurrences due to violent causes in the mobile emergency care Service.

\section{DISCUSSION}

Auto accidents, aggression and suicide attempts (self-inflicted violence) have been expressive recurrent demands of the mobile emergency services in many different Brazilian locations. They make up the traumatic events to which the mobile emergency services respond and were the second most common type of demand in a municipality in the state of Bahia (ROCHA; MORAIS; BENEVIDES, 2012).

Collisions, people ran over, motorcycle fall, cars rolling over, fire arm and/or melee weapon injuries and aggression made up to $78.2 \%$ of the traumatic occurrences to which an urgency service in a municipality at Rio Grande do Sul responded (CASAGRANDE; STAMM; LEITE, 2013). In a municipality in the state of São Paulo, auto accidents with motorcycles and car accidents, aggression and suicide attempts, were the most common occurrences dealt with by these services involving people from 20 to 59 years of age $(80.8 \%$, $65.0 \%, 80.5 \%$ and $81.8 \%$ of victims, respectively according to the cause of the problem, were in this age group) (ALMEIDA et al., 2016).

In the three different locations mentioned, the mobile service was more often needed by men (ROCHA; MORAIS; BENEVIDES, 2012;
CASAGRANDE; STAMM; LEITE, 2013; ALMEIDA et al., 2016), as was the case of this study.

Since external causes are the second most common cause of death in Brazil, the composition of the mobile emergency services is in an opportune position to help safeguarding the lives of these victims, since their death can often be avoided through qualified and opportune care - offered fast, in the site of the occurrence (SANTOS et al., 2012; VERONESE; OLIVEIRA; NAST, 2012; MURPHY et al., 2014; BEOJONE; SOUZA, 2017).

In addition to the planning of the working process of the mobile urgency service, the identification of the temporal distribution of the occurrences in spikes of cases is essential, as it is a measure that helps in the adequate preparation of the team and in the sizing of its resources for assistance (MURPHY et al., 2014; BEOJONE; SOUZA, 2017). As presented in this study, the results regarding the identification of periods of strong activity have potential to contribute to the improvement of the local nursing team. In another perspective, the identification of these periods collaborate to new investigations targeted at bringing forward the local or behavioral sociocultural relations in the lifestyle of the victims, that might explain the periods with a higher number 
of occurrences (be they months, days of the week/weekend or parts of the day.

According to the particularities discussed for the attention to violent causes in the mobile emergency services, the actions of the Nursing professionals become as important as they are complex. The nurse must contribute for the team to be responsibly involved in a way that is more than the simple control over their tasks (VERONESE; OLIVEIRA; NAST, 2012; O'DWYER \& MATTOS, 2013; LUCHTEMBERG et al., 2014). The scope of their actions needs to include measures that may safeguard the quality of attention to be offered in adequate time, coordinate the triple objectives of education, care and management - as to maintain the quality of the assistance offered by the team (LUCHTEMBERG et al., 2014; VELLOSO et al., 2014; LUCHTEMBERG; PIRES, 2016). Additionally, initiatives of the nursing team of the mobile emergency service, including their participation in intersectoral projects capable of intervening in situations of vulnerability - such as those involving violence - show themselves to be additional strategies to deal with these demands (VERONESE; OLIVEIRA; NAST, 2012; LUCHTEMBERG et al., 2014; VELLOSO et al., 2014; LUCHTEMBERG; PIRES, 2016).

Regarding the profile of the activities conducted by 63 nurses acting in a mobile emergency service in Brazil, an interview with these professionals indicated that $63.2 \%$ of their actions are related to direct care to the victims, $26.1 \%$ to administrative actions and $10.8 \%$ to educational actions (LUCHTEMBERG; PIRES, 2016). No research could be found that analyzed the correspondence between the composition of the nursing team and the profile of the victims of the cases to which the service responded, indicating that the data originating from the mobile emergency service as proposed by this study is unprecedented.

A limitation of this study was the fact that it used retrospective secondary data, and the analyzed sources presented restricted information, so that the profile of care did not contain data regarding age group and the severity of the cases. The analysis performed were exploratory, which means that further studies would be necessary to establish causal relations among the results found. Another limitation is the fact that the study took place in the context of one municipality, but its findings may correspond to similar ones.

At last, as a way to systematize information from the observations on the victimization of violence - through information originated from the mobile emergency care service, the analysis carried forth here presented itself as one with potential to guide the situational recognition of the composition of the nursing team in each location, and as such, it could give support to the optimization of the actions of the service, so that qualified attention can be offered as a response to these demands.

This study resulted in the identification of groups of similarities corresponding to the composition of the nursing team of a mobile emergency care service, as they were confronted with the profile of victims of violent causes who received attention from such services in a medium sized municipality in Triângulo Mineiro. Three specific groups were identified, according to the nursing professionals who took part in the attention to the cases, to the outcome of the occurrences, the period of the day in which it took place (hours) and the profile of the victim. The profile of the attention to occurrences with violent causes corresponded to that of other Brazilian locations, mostly involving men. An expressive percentage of the attention required from the service was due to violent occurrences, especially in auto accidents.

Temporal distribution pointed out an increase in the occurrences due to violent causes cared for, especially during weekends. A limitation of the study was the characterization of the profile of the victim regarding their age group and the severity of the occurrence. However, studies were found in which a multivariate analysis was carried out to systematize records of the mobile emergency services in order to identify correspondences between the composition of the team and the profile of the attention. Since this is an exploratory analysis, new researches must be carried out to identify causal relations that explain the demand for care in violent occurrences, and factors such as the periods with a higher number of occurrences. Another perspective indicates the need of a closer analysis of the working process of the nursing team studied, regarding its idiosyncrasies, dilemmas and potentialities, as they work to adequately safeguard the lives of victims of violence.

RESUMO: Objetivo: analisar o perfil de atendimento do serviço móvel de urgência em ocorrências de causas violentas e a atuação da equipe de enfermagem. Métodos: estudo observacional, exploratório e analítico de registros secundários. Empreendeu-se Análise de Correspondência para identificar associações entre a atuação da equipe de enfermagem e o perfil da demanda por causas violentas assistidas. Resultados: total de 
1800 ocorrências, entre as quais prevaleceram atendimentos no final de semana $(49,2 \%)$, aos homens $(70,0 \%)$, envolvendo acidentes de transito (76,5\%). A análise de correspondência privilegiou duas dimensões $(76,7 \%$ de contribuição explicativa), resultando em três grupos similares conforme trabalhador de enfermagem atuante no atendimento, desfecho da ocorrência, período e perfil da vítima. Conclusão: a análise se apresentou estratégica para sistematização de dados apoiadores à compreensão situacional do desempenho do serviço e planejamento do trabalho da equipe de enfermagem.

PALAVARAS-CHAVE: Médicos de Emergência. Enfermagem em Emergência. Equipe de Enfermagem. Causas Externas. Violência.

\section{REFERENCES}

ALMEIDA, P. M. V.; DELL'ACQUA, M. C. Q.; CYRINO, C. M. S.; JULIANI, CMCM; PALHARES, V. C.; PAVELQUEIRES, S. Analysis of services provided by SAMU 192: Mobile component of the urgency and emergency care network. Esc Anna Nery, Rio de Janeiro, v.20, n. 2, p. 289-95, 2016. http://dx.doi.org/10.5935/1414-8145.20160039

ALVES, M.; ROCHA, T. B.; RIBEIRO, H. C. T. C.; GOMES, G. G.; BRITO, M. J. M. Specificities of the nursing work in the mobile emergency care service of Belo Horizonte. Texto e Contexto Enferm, Florianópolis, v. 22, n. 1, p. 208-215, 2013. http://dx.doi.org/10.1590/S0104-07072013000100025

BEOJONE, C. V.; SOUZA, R. M. Application of the hypercube model with queue priorities and more than one preferential server: a case study on a SAMU. Gest Prod, São Carlos, v. 24, n. 4, p. 814-28, 2017. http://dx.doi.org/10.1590/0104-530x2452-16

BRICE, J. H.; STUDNEK, J. R.; BIGHAM, B. L.; MARTIN-GILL, C.; CUSTALOW, C. B.; HAWKINS, E.; MORRISON, L. J. EMS Provider and Patient Safety during Response and Transport: Proceedings of an Ambulance Safety Conference. PreHosp Emerg Care, Philadelphia, v. 16, n. 1, p. 3-19, 2012. http://dx.doi.org/10.3109/10903127.2011.626106

CASAGRANDE, D.; STAMM, B.; LEITE, M. T. Perfil dos atendimentos realizados por uma unidade de suporte avançado do serviço de atendimento móvel de urgência (SAMU) do Rio Grande do Sul. Sci Med, Porto Alegre, v. 23, n. 3, p. 149-155, 2013.

GONSAGA, R. A. T. Avaliação da mortalidade por causas externas. Rev Col Bras Cir, Rio de Janeiro, v. 39, n. 4, p. 263-267, 2015. http://dx.doi.org/10.1590/S0100-69912012000400004

INFANTOSI, A. F. C.; COSTA, G. C. D.; ALMEIDA, R. M. V. R. Análise de Correspondência: bases teóricas na interpretação de dados categóricos em Ciências da Saúde. Cad Saúde Pública, Rio de Janeiro, v. 30, n. 3, 2014. http://dx.doi.org/10.1590/0102-311X00128513.

BRAZILIAN INSTITUTE OF GEOGRAPHY AND STATISTICS. Censo Brasileiro de 2010. 2012. Disponível em: <http://www.ibge.gov.br>. Acesso em: 05 jan. 2017.

KONDER, M. T.; O'DWYER, G. As Unidades de Pronto-Atendimento na Política Nacional de Atenção às Urgências. Physis, Rio de Janeiro, v. 25, n. 2, p. 525-545, 2015. http://dx.doi.org/10.1590/S010373312015000200011

LUCHTEMBERG, M. N.; PIRES, D. E. P.; SCHOELLER, S. D.; POSSAMAI, F. P. Analysis of calls to the Mobile First-Aid Medical Services in a Brazilian capital city. Rev Rene, Fortaleza, v. 15, n. 6, p. 925-32, 2014. doi: http://dx.doi.org/10.15253/2175-6783.2014000600004 
LUCHTEMBERG, M. N.; PIRES, D. E. P. Nurses from the Mobile Emergency Service: profile and developed activities. Rev Bras Enferm, Brasília, v. 69, n. 2, p. 213-20, 2016. http://dx.doi.org/ 10.1590/0034$7167.2016690202 \mathrm{i}$

MURPHY, S. O.; BARTH, B. E.; CARLTON, E. F.; GLEASON, M.; CANNON, C. M. Does an ED flow coordinator improve patient throughput? Emerg Nurse, London, v. 40, n. 6, p. 605-12, 2014. http://dx.doi.org/10.1016/j.jen.2014.03.007

O'DWYER, G.; MATTOS, R. A. Integral Care and Attention to Emergency: the mobile emergency care service in the State of Rio de Janeiro. Saúde Soc, São Paulo, v. 22, n. 1, p. 199-210, 2013.

http://dx.doi.org/10.1590/S0104-12902013000100018

ROCHA, E. G. A.; MORAIS, A. C.; BENEVIDES, T. O. Serviço de atendimento móvel de urgência (SAMU) no município de Juazeiro (BA): principais especialidades demandadas. Rev Baiana Saúde Pública, Salvador, v. 36, n. 4, p. 1041-52, 2012. https://doi.org/10.22278/2318-2660.2012.v36.n4.a352

SANTOS, M. C.; BERNARDES, A.; GABRIEL, C. S.; ÉVORA, H. D. M.; ROCHA, F. R. L. O processo comunicativo no Serviço de Atendimento Móvel de Urgência (SAMU-192). Rev Gaúcha Enferm, Porto Alegre, v. 33, n. 1, p. 69-76, 2012. http://dx.doi.org/10.1590/S1983-14472012000100010

SOUZA, R. M.; MORABITO, R.; CHIYOSHI, F. Y.; IANNONI, A. P. Hypercube model extension for the analysis of emergencial medical systems with priority queue. Prod, São Paulo, v. 21, n. 1, p. 1-12, 2014. http://dx.doi.org/10.1590/S0103-65132013005000028

UNITED NATIONS. Health in the post-2015 agenda: Report of the global thematic consultation on health, 2013.

VERONESE, A. M.; OLIVEIRA, D. L. L. C.; NAST, K. Life risk and nature of SAMU: users' perspectives and implications for nursing. Rev Gaúcha Enferm, 2012; 33(4):142-8. doi: http://dx.doi.org/10.1590/S198314472012000400018

WILLIAMS, R. The role of nurses in ambulance services. Emerg Nurse, London, v. 20, n. 1, p. 2-22, 2012. http://dx.doi.org/10.7748/en2012.04.20.1.20.c9039 